\title{
Where the geographical expanse ends - Space education in primary school. Implementation of inquiry based science education (IBSE) in geography lessons in Polish school
}

\begin{abstract}
Inquiry based science education has been more and more popular strategy in teaching sciences in recent years. Transregional pressure put by international, standardized knowledge and skills tests (e.g. PISA) to converge curricula (Rundgren 2015) of different European states paradoxically helps to promote the open inquiry method which involves the student in the teaching process. Earlier research done in many countries such as Turkey, Israel, Sweden, The Czech Republic (Heinz et al. 2017), Ireland (Dunne et al. 2013) or The Netherlands (Uum van Martina et al. 2016) shows the increase of interest in IBSE both in Europe and in the world.

Teaching geography in Polish primary schools follows international educational trends. This study analyses several proposals of educational activities connected with Space which support geography teaching All of them are conducted with using open inquiry method, which is recommended in New National Curriculum of geography (Core Curriculum, 2017, Geography-classes V-VIII).

Keywords

Geography teaching $\cdot$ inquiry based science education (IBSE) • atmosphere $\cdot$ Space

(c) University of Warsaw - Faculty of Geography and Regional Studies
\end{abstract}

\author{
Jakub Sypniewski \\ Department of Geography Didactics and Ecological Education, \\ Faculty of Geographical and Geological Sciences, \\ Adam Mickiewicz University in Poznań, Poland \\ e-mail: jaksyp@amu.edu.pl \\ Received: 18 May 2018 \\ Accepted: 9 June 2019
}

\section{Introduction}

In the general Polish education system, nature education plays an important role and is represented by such school subjects as biology, chemistry, physics, geography and nature. Despite the constant increase in natural science knowledge, the fact that the number of hours devoted to nature education is declining is becoming worrying. The organisational change of the school system that we are currently witnessing mistakenly emphasises a return to the previous education system. Despite the restoration of the eight-year primary school cycle, the number of hours of science teaching did not return to its original level; on the contrary, it decreased from 1,015 hours in the school year to 700 (Czachorowski 2017). Also, the number of geography hours has been subject to the same trend and has been reduced from ten teaching hours (in an eight-year primary school cycle before the reform introducing middle schools) to five hours (in a modern eight-year primary school).

Academic geography has long been trying to face the problems of identity and separateness (Wiecki 2018). According to Chojnicki (1999), the uniqueness of geography as science is evidenced by the objects of its research and the systemic relations to which they are subject (especially spatial relations). When treating the landscape as a subject of geography research, human participation in its evolution should be taken into account Thus, the importance of geography in the order of science consists in the synthetic recognition of certain phenomena on the surface of the Earth, however, always in relation to man, as well as on the multilateral impact and mutual relationship of this science with the teaching of others (Pawłowski 1938).

Contemporary treatment of the natural environment as a whole is a consequence of the introduction of systems theory
(Allen Philip A. 2000). The integrative character of geography gives unusual opportunities for cooperation between different scientific disciplines. Undoubtedly, while conducting research, geography uses the results of other sciences, but the proper geographical survey begins only when geographical relations are found (Pawłowski 1938). In this light, attention should also be paid to the nature of school geography as a subject in education. In the introduction to the new core curriculum in geography for grades $\mathrm{V}-\mathrm{VIII}$, we read that the educational value of geography as a school subject results from integrating student's knowledge about the natural environment with socio-economic and humanistic knowledge (Core Curriculum 2017 Geography - classes VVIII). The integration character of geography is developed in geographic education at post-primary school level, assuming that the main goal for the students is to learn about their country and the world as an integrated whole, in which natural, socioeconomic phenomena and processes are closely related, based on the principles of mutual conditioning and dependence (Core Curriculum 2017 Geography - secondary school). Particularly noteworthy is the spatial range of interest in geography. It is not only limited to the surface of the area, but also covers the depth of the oceans, the interior of the Earth and its gas layer, which marks the upper limit of interest in geography as a science and therefore as a school subject.

\section{Aim of the study. Methods}

The main goal of this study is to recognise and evaluate the possibility of implementing the inquiry based science education (IBSE) strategy in teaching geography lessons connected with Space topics. Several proposals of educational 
initiatives which support geography teaching are presented in this article. The analytical work carried out within the research included documents such as Core Curriculum and educational proposals from ESERO-Poland, Sally Ride EarthKAM and Space Awareness. Thanks to participant observation of the teachers' workshops and student activities related to Space, it became conceivable to recognise the possibility of introducing the IBSE strategy in classes. Such observation is a specific way of perceiving, gathering and interpreting data in the natural course of events. The data are usually within sight or hearing distance of the observer (Łobocki 2000). This method is characteristic for not only sciences (including geography) but also for educational studies and it is connected with purposeful, planned and systematic perception of a studied subject, process or phenomenon (Sztumski 1999). An additional advantage of the observations conducted was the involvement of the author who became part of the observed environment, which enabled the thorough analysis of what the students and teachers were doing while working in groups.

The comparative method is based on comparing phenomena, activities, things, concepts, assertions (Zieliński 2012). Comparisons that belong to the basic cognitive functions consist in determining the existence or absence of the same qualitative traits, the same or different varieties of qualitative traits, as well as the same, similar or different degree of intensity of the same features occurring in different objects and phenomena (Stachak 2006, in Szarucki 2010). The result of conducting comparative research is, therefore, the finding of the identity of the things compared (Pieter 1967). The content of the chapters of the "old" and "new" core curriculum of general education in geography, which concern issues related to the place of the Earth in the Universe, orientation in the field (Table 1), and the construction of the atmosphere were subjected to the research. The comparison of the sections of the "place of the Earth in the Universe" and "orientation in the field" are presented in the rows of Table 1. The content has been divided into problem groups (in the column "Issues from chapters related to the place of the Earth in the Universe and orientation in the field"), to which further requirements stored in the core curriculum have been assigned. The occurrence of a given issue in both analysed documents means the determination of a partial identity. The lack of such an identity is marked with the symbol " $X$ ". The results of the atmosphere construction topic are different, which is consistently not a separate issue in geographic education at this stage of schooling. Thanks to the comparative method, the possibility of using the content or tools of ESERO-Poland, Sally Ride EarthKAM and Space Awareness, educational proposals are made available for geography teachers.

Topics connected with atmosphere and Space in Polish Core Curriculum 2017 Geography - classes V-VIII

According to Tkocz (2008), geography is treated as the scientific field concerning the spatial variety of the Earth's spheres and the relationships between their parts and human activity. There is no clear-cut definition of the upper boundary line of the Earth's spheres (geographic space), thus scientists marked this symbolic line of the atmosphere at different altitudes. Authors of Polish academic handbooks of meteorology and the World Air Sports Federation both propose different values for this line. The World Air Sports Federation considers the Kármán line, which is a symbolic line at an altitude of $100 \mathrm{~km}$ above which the atmosphere is too thin to support aeronautical flight, to be the upper boundary of the atmosphere ( $A$ brief history of space, 2017). In the academic handbook Meteorology and climatology by K. Kożuchowski (2005) there are two values which mark the upper boundary of the atmosphere: 10,000 km, and a commonly accepted value of $1,500 \mathrm{~km}$. According to A. Woś (2006), it is practically impossible to specify where this boundary lies, because the Earth's atmosphere does not have a clear boundary as it gradually transforms into the interplanetary space, and its traces can even be found at an altitude of tens of thousands of kilometres.

Neither the "old" nor the "new" core curriculum stresses the layered structure of the atmosphere or the range of its upper limit. Building the atmosphere in geographic education in a Polish primary school, as well as the phenomena that occur in it, are mostly limited to introducing issues regarding weather components, including reading their value or naming measurement devices. Often, students can name weather elements such as atmospheric pressure or wind, in fact not knowing the genesis or course of these elements. Experiments are possible to be implemented in the process of geographic education (especially in topics related to the Earth's atmosphere in order to better understand selected issues) do not appear in the new core curriculum. The task where the "pupil performs and describes simple experiments demonstrating the existence of air and atmospheric pressure", which was in force until 2017 in nature education in classes IV-VI disappeared. Significant changes are also visible in the issues raised within the "Earth in the Universe" themes (Table 1). Understandably, the main area of interest in geography is the movements of the Earth, the characteristics of which is an important element of primary school education. Although the new core curriculum emphasises the content and requirements of geographic education in a more detailed way, the correction of the substantive scope of the programme is evident in the case of the issues raised, e.g. in the areas of description of the shape of the Earth, construction of the solar system, heliocentric theory of the construction of the Universe or the boundary of the date change line.

Inadequate specification of the upper boundary of interest of geography as science as well as a frequent lack of interest of other school subjects in topics concerning Space and finally a decreasing amount of content about the Earth's atmosphere in geography lessons lead to the question of whether the Universe can and should be the subject of considerable interest of geographic sciences in reorganised primary schools. Geography is also linked to Space by an important subdiscipline - geoinformation - which is particularly stressed in the new core curriculum. The European Space Education Resource Office-Poland also stresses the importance of geography in Space education. In the description of its activity on its webpage, ESERO claims that geography, along with physics, introduces Space topics in lessons. ESERO also encourages teachers of other subjects to cooperate in this area (About ESERO, 2017).

Paradoxically, the chance to introduce the aforementioned content is possible in the new core curriculum, which allows teachers to authorise 20 per cent of the geography material at their own discretion, including expanding selected teaching content, and results from the minimum number of hours allocated for the implementation of the subject.

Inquiry based science education in teaching geography

Teaching geography as well as other scientific subjects by presenting them in the context of Space education may lead to increasing students' interest in learning, and motivating them to search for knowledge on their own. Observing the whole learning cycle (on which IBSE is based), it is clear that the word "strategy" is a more appropriate expression to describe inquiry based education. A method is a pattern of behaviour used in gaining knowledge and skills that can be regularly repeated (Okon 1998), whereas the model of a learning cycle consists in applying many methods such as: guided discussion, 
MISCELLANEA GEOGRAPHICA - REGIONAL STUDIES ON DEVELOPMENT

Vol. 23 • No. 4 • 2019 • pp. 256-266 • ISSN: 2084-6118 • DOI: 10.2478/mgrsd-2019-0024

Table 1. Topics connected with Space in "old" and "new" Polish Core Curriculum Geography

\begin{tabular}{|c|c|c|c|}
\hline \multicolumn{2}{|c|}{$\begin{array}{c}\text { Issues from chapters related } \\
\text { to the place of the Earth in the } \\
\text { Universe and orientation in the } \\
\text { field }\end{array}$} & $\begin{array}{l}\text { The "old" core curriculum } \\
\text { Nature (classes IV-VI) } \\
\text { Geography (grades I-III middle } \\
\text { school), } \\
\text { student: }\end{array}$ & $\begin{array}{l}\text { The "new" core curriculum } \\
\text { Nature (class IV) } \\
\text { Geography (classes V-VIII), } \\
\text { student: }\end{array}$ \\
\hline \multirow{2}{*}{\multicolumn{2}{|c|}{ Shape and location of the Earth }} & $\begin{array}{c}\text { describes the shape of the Earth using } \\
\text { its model - the globe; gives the main } \\
\text { features of the shape and dimensions of } \\
\text { the Earth }\end{array}$ & $x$ \\
\hline & & $\begin{array}{c}\text { lists the names of the planets of the Solar } \\
\text { System and organises them according to } \\
\text { the distance from the Sun }\end{array}$ & $\mathrm{X}$ \\
\hline \multicolumn{2}{|c|}{$\begin{array}{l}\text { The history of knowing the structure } \\
\text { of the Solar System }\end{array}$} & \begin{tabular}{|c|} 
explains the assumptions of the \\
heliocentric theory of Nicolaus Copernicus
\end{tabular} & $x$ \\
\hline \multirow{2}{*}{\multicolumn{2}{|c|}{ Light phenomena }} & $\begin{array}{c}\text { examines experimentally the straight } \\
\text { line propagation of light and its } \\
\text { consequences, e.g. Camera Obscura, } \\
\text { shadow }\end{array}$ & $x$ \\
\hline & & $\begin{array}{l}\text { investigates the phenomenon of light } \\
\text { reflection }\end{array}$ & $x$ \\
\hline \multicolumn{2}{|c|}{$\begin{array}{l}\text { Mechanism of rotational and } \\
\text { circulating motion of the Earth }\end{array}$} & $\begin{array}{l}\text { presents the Earth's rotational and } \\
\text { circulating motion with the help of the } \\
\text { model; gives the characteristics of the } \\
\text { rotary motion; gives the characteristics of } \\
\text { the Earth's circular motion }\end{array}$ & $\begin{array}{l}\text { demonstrates using the models (e.g. a } \\
\text { globe or tellurium) the rotational motion of } \\
\text { the Earth; determines its direction, duration, } \\
\text { places of sunrise and sunset, and solar noon; } \\
\text { demonstrates using planetary (e.g. tellurium or } \\
\text { globe model) motion models }\end{array}$ \\
\hline \multirow{6}{*}{$\begin{array}{l}\text { Consequences } \\
\text { of the Earth's } \\
\text { rotational and } \\
\text { circulating motion }\end{array}$} & Day and night & $\begin{array}{c}\text { finds the relationship between the Earth's } \\
\text { rotational movement and the change of } \\
\text { day and night }\end{array}$ & $\begin{array}{l}\text { explains the relationship between the rotational } \\
\text { movement and (...) the existence of day and } \\
\text { night, the daily rhythm of human life and nature }\end{array}$ \\
\hline & $\begin{array}{l}\text { Visible } \\
\text { wandering of } \\
\text { the Sun }\end{array}$ & $x$ & $\begin{array}{l}\text { describes changes in the position of the Sun } \\
\text { above the horizon during the day and during the } \\
\text { year; indicates on the terrain and on the diagram } \\
\text { (or horizon) of the place of sunrise, sunset and } \\
\text { the Sun towering during the day and at different } \\
\text { times of the year; explains the relationship } \\
\text { between the rotational movement and the visible } \\
\text { wandering and towering of the Sun }\end{array}$ \\
\hline & $\begin{array}{l}\text { Seasons, } \\
\text { lighting of the } \\
\text { Earth }\end{array}$ & $\begin{array}{l}\text { shows the relationship between the } \\
\text { planet's circulation and the changes of } \\
\text { the seasons; presents (also using own } \\
\text { observations) changes in the Earth's } \\
\text { lighting and in the duration of day and } \\
\text { night in different latitudes and seasons }\end{array}$ & $\begin{array}{l}\text { presents changes in the Earth's lighting in the } \\
\text { first days of astronomical seasons }\end{array}$ \\
\hline & $\begin{array}{l}\text { Solar time and } \\
\text { zone time }\end{array}$ & $\begin{array}{l}\text { uses the following concepts with } \\
\text { understanding - rotational movement } \\
\text { of the Earth, solar time, zone time; } \\
\text { explains why time zones and date change } \\
\text { boundaries were introduced; uses the map } \\
\text { of time zones to determine the difference } \\
\text { between zoning and solar time on Earth }\end{array}$ & $\begin{array}{l}\text { explains the relationship between rotational } \\
\text { motion and the occurrence of time zones }\end{array}$ \\
\hline & $\begin{array}{l}\text { The height of } \\
\text { the Sun above } \\
\text { the horizon }\end{array}$ & $\begin{array}{c}\text { sees the relationship between the altitude } \\
\text { of the Sun, the length of the day and the } \\
\text { air temperature during the year }\end{array}$ & $\begin{array}{l}\text { explains the relationship between the altitude } \\
\text { of the Sun and the length and direction of the } \\
\text { shadow; measures the altitude of the Sun during } \\
\text { fieldwork and compares the results obtained at } \\
\text { different times of the day and year }\end{array}$ \\
\hline & $\begin{array}{l}\text { Lighting zones, } \\
\text { landscape } \\
\text { zones }\end{array}$ & $x$ & $\begin{array}{l}\text { shows the relationship between the Earth's } \\
\text { circulation and its lighting zones, and the zonal } \\
\text { diversity of the climate and landscapes on Earth }\end{array}$ \\
\hline
\end{tabular}

Source: prepared on the basis of Core Curriculum 2002 and Core Curriculum 2017 
brainstorming, debate, observation, measurement, case study or organising presentations and experiments. Thus, in this paper, the expression "strategy of inquiry based teaching" is used. There is still confusion among both researchers and teachers about the precise explanation of "inquiry" and how best to carry it out (Anderson 2002; Newman et al. 2004, in Dunne et al. 2013). By definition, inquiry is the intentional process of diagnosing problems, critiquing experiments, and distinguishing alternatives, planning investigations, researching conjectures, searching for information, constructing models, debating with peers, and forming coherent arguments (eds Bell, Davis \& Linn 2004, as cited in the Rocard Report: Science Education Now: A New Pedagogy for the Future of Europe 2007).

The changes in science teaching both in Europe and the whole world are undoubtedly connected with the introduction of open inquiry methods in the education process (Rocard Report 2007, Dunne et al. 2013, Rundgren 2016, Uum van Martina et al. 2016, Heinz et al. 2017). However, the popularisation of the IBSE strategy is not always reflected in updates of teacher training courses at universities. These courses are to prepare for teaching sciences, including geography. Not only state organisations but also private institutions play a role in making IBSE popular among teachers (Heinz et al. 2017). Teachers do not need recipes on how to implement IBSE activities but flexible resources (Balzano 2016). The European Space Education Resource Office-Poland and the Copernicus Science Centre are important centres in Poland which help teachers to improve qualifications. They promote IBSE strategy, especially in the Space context, including the preparation of lesson plans or teachers' courses. The Copernicus Science Centre offers among other things: participation in training (Copernicus in the field, PowerBox, Spacecraft Materials Kit); conferences (Lay out-Let out Conference, Space in the school); or making the Internet database public (a recommendation for the science laboratory is available on the webpage of the Copernicus Science Centre). Educational reform in Poland or rather organisational change of the school (Czachorowski 2017) and, as a result of its introduction, The New Polish Core Curriculum supports teachers' autonomy - it encourages them to modify the content of geography education (leaving the teacher the opportunity to adjust the subject in about 20 per cent of the classes). The purpose of teaching about Space in classes (also geography) is to increase students' interest in science.

The IBSE strategy is based on the model of a learning cycle. The idea of a learning cycle as a model of teaching sciences was presented for the first time by Robert Karplus and J. Myron Atkin (Lawson 1958). In 1961 Karplus, a physicist inspired by his teaching experience while working at Berkeley (California), began implementing a study plan consisting of students' observations and experiments accompanied by analytical interpretation. In 1962 R. Karplus in cooperation with J. M. Atkin formulated a theory of guided discovery. Even though its name did not contain the expression "learning cycle", this was undoubtedly its initial phase. It basically assumed two phases of teaching: the first one - an initial introduction of a new concept (also known as invention); and the second one - later verification or extension of the concept (also known as discovery). This method was not really a new discovery, which was also stressed by its authors; it was an analogy to great scientific discoveries from the past which in fact it was based on (e.g. the interpretation of the movement of the Sun and planets). At the same time, genetics professor Chester Lawson from Michigan University presented similar views in his work Language, Thought and The Human Mind (Lawson 1958). For the first time the expression "learning cycle" appeared in the Teacher's Guide for Programme SCIS (Science Curriculum Improvement Study). It is probably correct to say that it is not possible to determine today who first proposed the

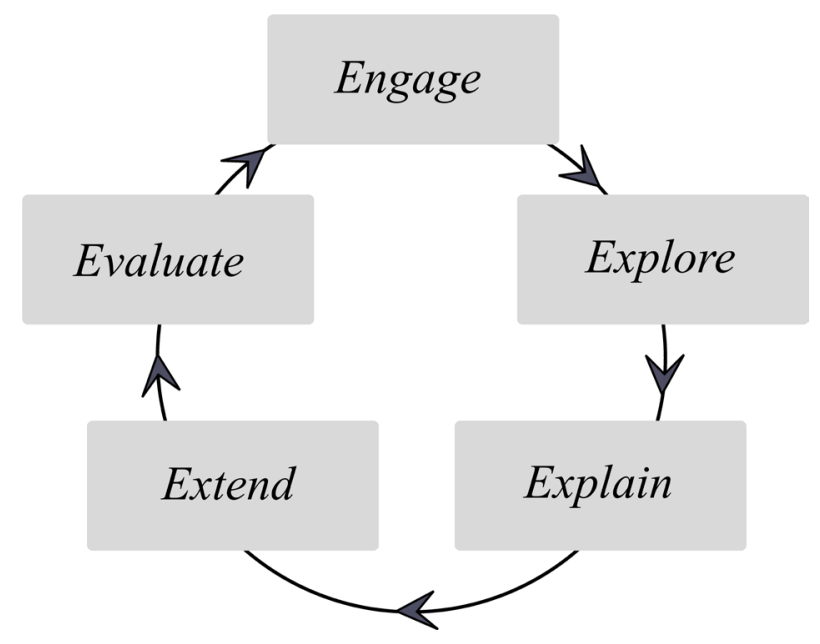

Figure 1. Modern model of learning (The 5 E's) Source: Bybee R. W. 1989

learning cycle (Lawson et al. 1989). It is certain, however, that our knowledge about education is still developing, so the learning cycle itself is evolving which enables more and more efficient teaching. A five-phase model of learning, i.e. The 5 E's (Engage - Explore - Explain - Extend - Evaluate) functions nowadays (Fig. 1) (Bernard P. et al. 2015; Sypniewski 2015a, 2015b).

Inquiry based education attaches great importance to the first stage of the learning cycle - involvement, due to which pupils become intrigued and emotionally connected with the subject, which is directly bound to their involvement. Emotional and cognitive processes are strongly linked, they act on each other and psychologists have opposing views as to which we developed first: emotions before cognition or cognition before emotions (Doliński 2000, in Kopeć 2005). Writing about the so-called "importance of a sparkle in the eye", M. Żylińska also stresses the special significance of the biological grounding of cognitive curiosity and enchantment as crucial conditions in the learning process (Żylińska 2013, in Cichoń \& Piotrowska 2016). For instance, when introducing the subject of soils in Poland, it can be extended by referring to a Space aspect. Then, instead of Soils in Poland, the topic of the lesson could be formulated as, for example, can we find a soil similar to Martian soil in Poland? The students can compare the properties of selected soils from Poland with a sample of Martian soil created according to European Space Education Resource Office guidelines. This topic can be successfully continued during biology or chemistry lessons, for example, by detecting evidence of life in Martian soil. Sciences in Polish schools, which are divided into biology, chemistry, physics or geography, do not help to gain knowledge in a holistic way. However, looking at the topic from the point of view of different subjects enables it to be extended by the next cycle and that, in turn, helps to maintain continuity of acquiring knowledge and skills connected with the specific school subjects.

\section{Types of classes based on IBSE}

The IBSE strategy, which teachers can apply at any stage of education, is based on four activities which assume a different level of teacher's or student's engagement. It is recomended to start using the strategy from the methods which involve the student to a lesser extent to those that gradually introduce open inquiry. The teaching methods can be used in any order. When covering the material, the teacher can stress one or two methods, because it is not necessary to apply all methods within one 
MISCELLANEA GEOGRAPHICA - REGIONAL STUDIES ON DEVELOPMENT

Vol. 23 • No. 4 • 2019 • pp. 256-266 • ISSN: 2084-6118 • DOI: 10.2478/mgrsd-2019-0024

Table 2. Levels of inquiry

\begin{tabular}{|c|c|c|c|}
\hline \multirow{2}{*}{ Level of inquiry } & \multicolumn{3}{|c|}{ Information given to students } \\
\cline { 2 - 4 } & Question & Methods & Solution \\
\hline 1 - confirmation & $\mathrm{X}$ & $\mathrm{X}$ & $\mathrm{X}$ \\
\hline 2 - structured inquiry & $\mathrm{X}$ & $\mathrm{X}$ & \\
\hline 3 - guided inquiry & $\mathrm{X}$ & & \\
\hline 4 - open inquiry & & & \\
\hline
\end{tabular}

Source: Bell, Smetana \& Binns 2005

lesson or even one full cycle of classes. A wide range of teaching possibilities enables the teacher to avoid school monotony. Using the same methods or even one method of teaching is criticised by pedagogists and psychologists. W. Okoń (1998) quoted B. Nawroczyński who "thought the monotony of teachers' methods to be the sole reason for school boredom". Within IBSE there are a few types of activities which to a different extent influence the involvement of a teacher and a student (Table 2). The " $X$ " mark indicates the information that students receive from the teacher at each level of inquiry.

\section{Confirmation}

This is the easiest teaching method used by inquiry based education. Even though the students' participation is limited to a minimum, they can see the stages of scientific inquiry within a single cycle. Confirmation means that from the very beginning of the investigation everything is already known; the goal is only to confirm (show and discuss) the effect of the experiment. During the demonstration, the teacher's task is to control the whole process of observation and investigation starting from posing a research question, through the selection of a few or one researched hypothesis, instructing the students how the data and experiment results should be analysed, and finishing by giving instructions on how to present the obtained results. The teacher maintains communication with the student by asking questions which lead the student through all elements of the cognitive cycle.

\section{Structured inquiry}

This assumes the role of the student is increasing in a scientific inquiry. The teacher asks a very general research question and proposes possible hypotheses. The students perform an experiment on their own, for which they receive the whole instruction as well as the necessary equipment and materials. The student's task is to draw conclusions on the basis of the performed experiment or experiments. The conclusions are an explanation of the initial research question.

\section{Guided inquiry}

After receiving the introductory information in which a research question is asked, the students propose their hypotheses and then programme and perform experiments on their own. The materials the students get allow them to present the investigated phenomenon in a few different ways. The pupils can perform one or a few experiments which enable them to answer the hypotheses. During the debate the teacher helps the students by asking questions. The students do not have to use all the materials and they decide themselves which of these will be necessary to research the given phenomena, properties or natural processes. On the basis of the obtained results, they draw conclusions taking into account the guidelines given by the teacher.
Open inquiry

In this method the students receive only a general topic of scientific inquiry from the teacher. The participants specify the research problem themselves and they prepare a list of teaching aids which will be needed to conduct experiments. Different aids are available on the table for all students and each pupil or a group chooses the ones that can be useful. At this stage the teacher is a passive observer, but to maintain safety, he or she controls the experiment. This level requires the greatest involvement, considerable independence and ease in scientific reasoning from the students.

The whole learning cycle in each of the above phases is achieved only when the conclusions are drawn and the answers to hypotheses and research questions are found. At the same time, the obtained solutions can inspire the students to ask new questions which require narrowing or further research. In this case a single learning cycle is not fully closed and subsequent research and scientific inquiry can be a pretext for future classes or a pupil's individual work, e.g. at home after school. The presentation of students' results is an often neglected stage. It must be stated that this time is crucial for participants of the classes, because then they can discuss their conclusions in front of the whole group.

An advantage of the IBSE strategy is that it works by organising so-called indirect teaching (Dylak 2013). In a learningteaching environment which allows mistakes to be made and, at the same time, creates partner-like relationships between the teacher and the student, it is possible to involve participants in the teaching process. Learning is not acquiring somebody else's ideas, but social negotiations of meaning (Klus-Stańska 2010). Education needs a dialogue between the teacher and the student, and among the students themselves, which is possible when applying IBSE. Scientific inquiry forces the teacher to pass the initiative into students' hands, to give up the role of the wise man and to become a participant. S. Dylak (2013) claims that "today's teacher may be recommended some silence and reduction of presenting his or her knowledge during lessons".

\section{Space education sector in Poland}

The introduction of Space topics in geography lessons is justified in the teaching strategy of IBSE. The offer of the Space education sector in Poland aimed at both students and teachers is very attractive at present. Selected proposals of educational activities connected with Space which support geography teaching by open inquiry and at the same time fulfil the assumptions of the New Curriculum for geography in grades V-VIII (2017) are presented in this work. 


\section{Sally Ride EarthKAM}

The international programme Sally Ride EarthKAM is aimed at students and teachers in all types of schools. Before joining the programme, the authors offer a wide range of lesson plans to be used at school to better prepare for satellite photos interpretation. The lesson plans database (in English) is free and available at https://www.earthkam.org. After creating an account and registering for the nearest mission (there are three to five missions per year), the students receive codes, thanks to which they can turn to the International Space Station to intercept photographs taken from the Station of almost every place on Earth above which the ISS is flying at the time. The high-definition satellite pictures that the school receives are very good material for further processing. These photographs can be used to show cardinal directions of a given picture, draw boundaries of states, name characteristic geographical objects, e.g. reservoirs, mountain ranges, summits, or give coordinates of the photographed objects. Due to the Space activity, the students can be involved in a range of tasks included in the curriculum for geography, i.e. "they show characteristic meridians, give cardinal directions, read mathematical-geographical positions of points or show relationships between zonal differentiation of landscapes on Earth" (Core Curriculum 2017 Geography classes V-VIII). Classes based on IBSE within the Sally Ride EarthKAM programme are of guided-inquiry type. The teacher's role is to present a research problem and an investigation aim to groups of students and to provide them with access to necessary tools (prior account opening, registering for the nearest ISS mission, distributing codes for taking pictures). Example research problems and aims are presented below.

- $\quad$ Research problem (first example): are there terrain features which naturally mark out state boundaries?

- Aim of the classes: to provide characteristics of the boundaries of selected countries in the world.

- Research problem (second example): is Africa a typical desert continent?

- Aim of the classes: to describe how land is used in Africa.

The ESERO-Polska project

The European Space Education Resource OfficePoland (ESERO-Polska) is an educational programme of the European Space Agency (ESA), whose coordinator in Poland is the Copernicus Science Centre (Centrum Nauki Kopernik). The programme supports Polish teachers in improving Space qualifications, prepares films and lesson plans to be used from the early stages of primary education and for different age groups. It also prepares students and teachers for international competitions, for example, Astro Pi. Every year teachers from Poland take part in the conference Space at school to practically learn the possibilities of implementing Space topics in different subjects. Lesson plans prepared with the help of the meetings' participants are part of an open access database of educational materials available in Poland after registering on the webpage http://esero.kopernik.org.pl. To use materials in English, there is a Teachers' corner tab on the official website of ESERO: http:// www.esa.int/Education/Teachers_Corner.

Lesson ideas connected with using geoinformation techniques are especially worth mentioning. A few examples are: Teledetekcja - zdjęcia satelitarne w sytuacjach kryzysowych [Teledetection - satellite photographs in emergency situations]; Satelitarne obserwacje Ziemi - przewodnik po wybranych zasobach danych satelitarnych przydatnych do celów dydaktycznych [Satellite observations of Earth - a guide of selected sources of satellite data useful for educational purposes]; Zmiany $z$ orbity [Changes from orbit]; $W$ którym miejscu Ziemi się znajdujesz? [Where on Earth are you?]; classes with the construction of a sextant to specify the latitude; or the film Mr Copernicus: wprowadzenie do Europejskiego Programu Monitoringu Środowiska [Mr Copernicus: an introduction to the European Programme of Monitoring the Environment]. The lesson ideas enable the students to master skills of finding their bearings, both by using modern tools and in a traditional way (e.g. with the help of Pole Star). Due to the data obtained from the Copernicus programme, the students can better understand the relations between the elements of the geographical environment and apply the rule of sustainable development on a global scale, which directly results from the general aims of geographical education in terms of knowledge. On the other hand, practical skills of specifying the latitude or the analysis of satellite photos fulfil the general aims of geographical education in terms of skills and applying the knowledge in practice (Core Curriculum 2017 Geography - classes V-VIII).

A wide range of materials offered by ESERO aids conducting various types of classes using the IBSE methodology. An example of implementing the open inquiry method is the new educational Spacecraft Materials Kit (instructional films and materials are available on the ESERO homepage in the Teachers' corner tab), which enables the properties of substances to be investigated in order to construct a spaceship which will pass through the Earth's atmosphere without losing the crew or the load inside it. In this case the teacher only submits the topic and leaves recommended materials, and the students themselves define research problems, form hypotheses and set research aims. If these are the first classes about the atmosphere, it is worth attracting the students' attention to the properties of the atmosphere that hinder movement of objects in Space. An example topic of the classes is presented below.

- Topic of the classes (defined by the teacher): what materials (and why) should be used to build a spaceship which can pass through the Earth's atmosphere unharmed?

- Research problem (students' proposal): are metals the best construction materials for a spaceship?

- Aims (students' proposal): 1) assessment of the application of metals in the spaceship construction from the point of view of their thermal conductivity, magnetism and mass; 2) comparison of the researched metal properties with the properties of other substances proposed by other groups.

\section{Space Awareness}

The aim of the project Space Awareness is to interest children and teenagers between the ages of eight and eighteen in Space, in the possibilities of a future career in this area, and to pay attention to current problems relating to the natural environment of our planet. Space Awareness includes four thematic blocks: our wonderful Universe, our fragile planet, navigation through the ages, the journey of ideas. Each block offers a wide range of lesson plans, educational materials to be carried out at school (they are available only in English). The students can understand, for example, the mechanism of the formation and evolution of tropical cyclones using a special application or can observe the increase in light pollution caused by man on the basis of the interactive map database. In May 2017 Polish Space Awareness and Czech ESERO organised workshops for Polish and Czech science teachers which took place in the Izera Dark-Sky Park located in the Izera Mountains on the Polish-Czech border. During the workshops the teachers had the possibility of testing different practical exercises such as building and testing the durability of ablative shields, the structure of meteorites, rocket construction or sky observation at night by means of applications that can be used at school.

The topic of ablative shields directly connected with commodity science and properties of solid bodies can be used 


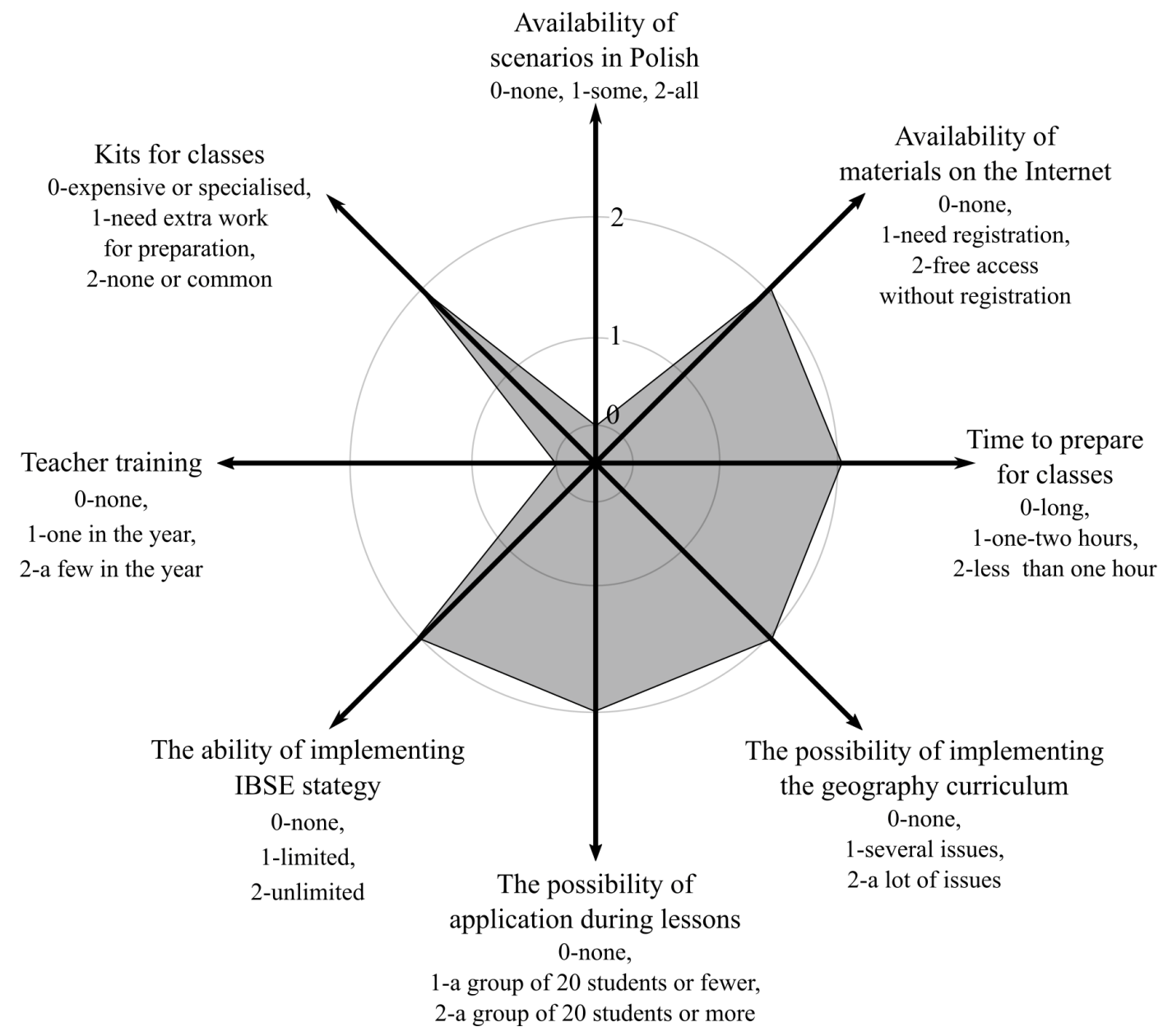

Figure 2. Sally Ride EarthKAM evaluation chart

Source: prepared on the basis of Sally Ride Science 2014

when discussing the structure of the atmosphere in geography lessons. On the one hand, the high temperature, symbolised by a flame (occurring when objects pass through the gaseous layer surrounding the Earth), hinders spaceships passing through; on the other hand, it is a protective barrier for mankind against space objects of small sizes, e.g. meteorites. During classes students burn an egg for five minutes in the flame of a burner attached to a special construction. The aim of these classes is to create such an ablative shield that will not allow the shell to char or the egg white to coagulate. Building shields from different materials that the students obtain is an example of bounded inquiry. The teacher presents the research problem and gives the materials that can be used by the lesson participants. The width of the shield (not more than the width of a standard pencil) and virtual money that the students have at their disposal are the only restrictions. Since different materials have different values, the decisions of constructors must be well thought out during their research inquiry.

\section{Critical evaluation of educational proposals}

Thanks to the participant observation of the teachers workshops and student activities eight criteria were selected to carry out the assessment of the presented educational proposals from the teachers' point of view. They are tightly connected with the three areas: technical, availability, and application:

- $\quad$ availability of scenarios in Polish (published on the Internet),

- availability of materials on the Internet (scenarios in languages other than Polish, films, different educational materials),

- $\quad$ time to prepare for classes (for teacher, before classes),

- the possibility of implementing the geography curriculum (in this article, only the Polish curriculum is taken into account),

- the possibility of application during lessons (45- or 90-minute classes),

- the ability to implement IBSE strategy (different kinds of strategy),

- the availability of teacher training (i.e. workshops and other training courses),

- kits necessary for classes (materials which the teacher should buy or create themselves).

The results of the interviews with workshop participants were presented in the form of wind rose charts. Every criterion has a gradual three-part scale that is described under its name. 


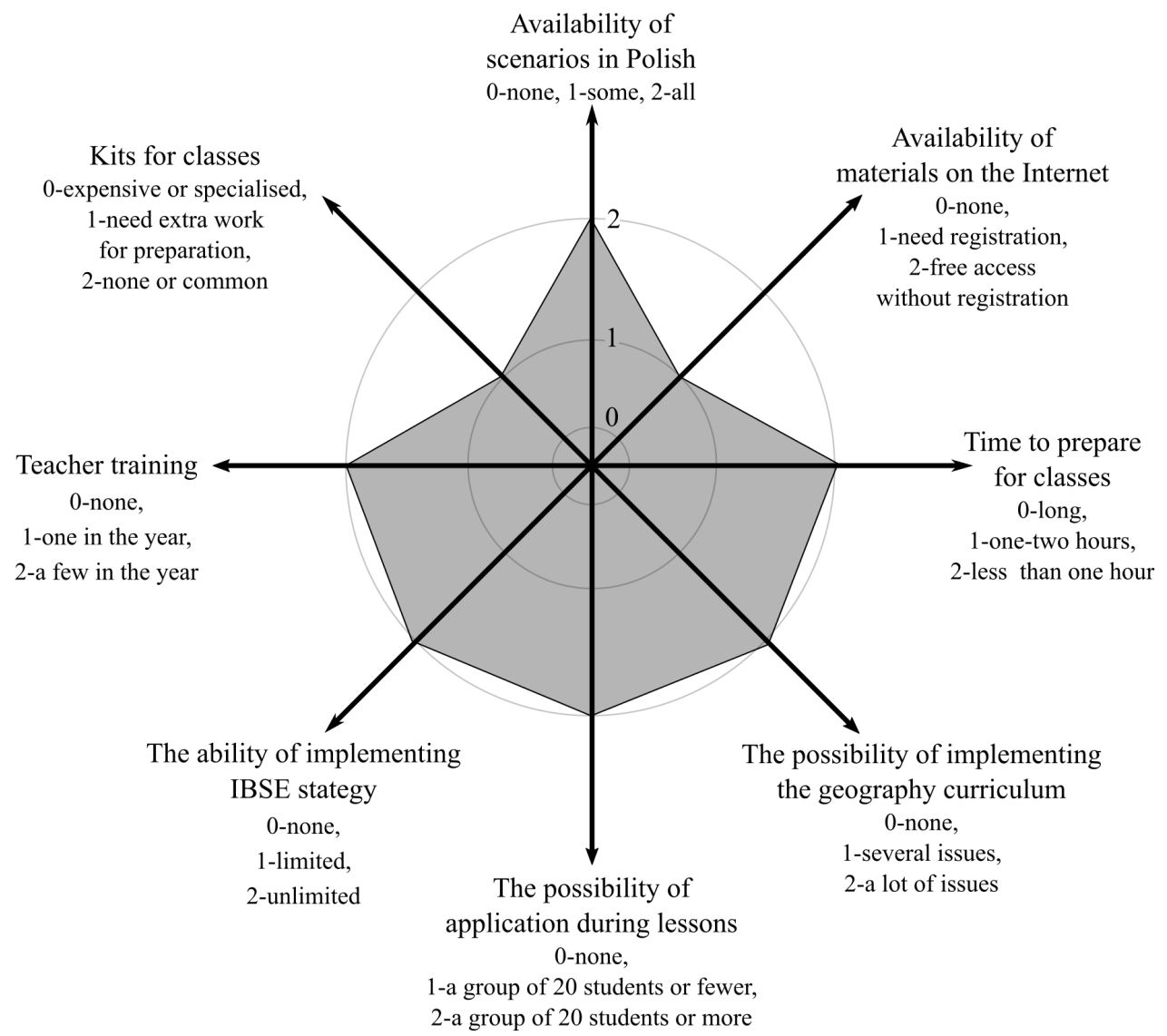

Figure 3. The ESERO-Polska project evaluation chart

Source: prepared on the basis of the European Space Education Resource Office 2017

\section{Sally Ride EarthKAM}

Six of the eight criteria scored the highest rating (Fig. 2). The main obstacle for Polish teachers is the lack of lesson scripts in Polish. There are no workshops for participants; however, there is a precise pdf instruction manual: how to take part in the Sallymission project (but this is also in English). To get access to the materials database, registration is needed. It must be highlighted that Sally Ride EarthKAM educational proposals could be used during classes with groups of more than 20 students and all of them could participate in the geography curriculum.

\section{The ESERO-Polska project}

In contrast to the earlier project, there is a rich scenarios database in Polish available after registration (Fig. 3). ESERO educational proposals could be used not only during geography or science but also biology, chemistry or mathematics classes. There is a large variety of different scripts for all educational levels, but some need extra preparation work (for example one of them requires building a rocket launcher for compressed air which later can be used many times).

\section{Space Awareness}

The last wind rose chart is the most variable one. Only two criteria scored the highest rating - availability of materials on the Internet and possibility of implementing the geography curriculum (Fig. 4). There are only Polish headings on the Polish website of this project, but the rest of the content is available in English (all without registration). Some of the proposals, like building ablative shields require a lot of time for preparation (from collecting materials to building construction for burning covers) and are less likely to be carried out in a big group of students for security reasons. On average, once a year Space Awareness organises a teachers' workshop, but it doesn't always take place in Poland.

All charts were compared in Figure 5. The main advantage of all three proposals is the possibility of implementing the geography curriculum during Space activities. Two areas were given the highest rating only once. There is a need to translate Internet resources into Polish, because for many teachers English is still an obstacle to their work. Another area requiring reorganisation are workshops and training for teachers. The training available in Poland should be increased in order to spread the idea of teaching about Space in combination with science subjects and the IBSE strategy. Another highly rated aspect is the possibility of using the scenarios during classes, which is frequently impossible at school because the time allocated for one lesson is not sufficient. Two of the three activities allow the implementation of the IBSE strategy (or some elements of this strategy).

\section{Conclusions}

The New Curriculum for geography in primary schools recommends abandoning expository methods and implementing 


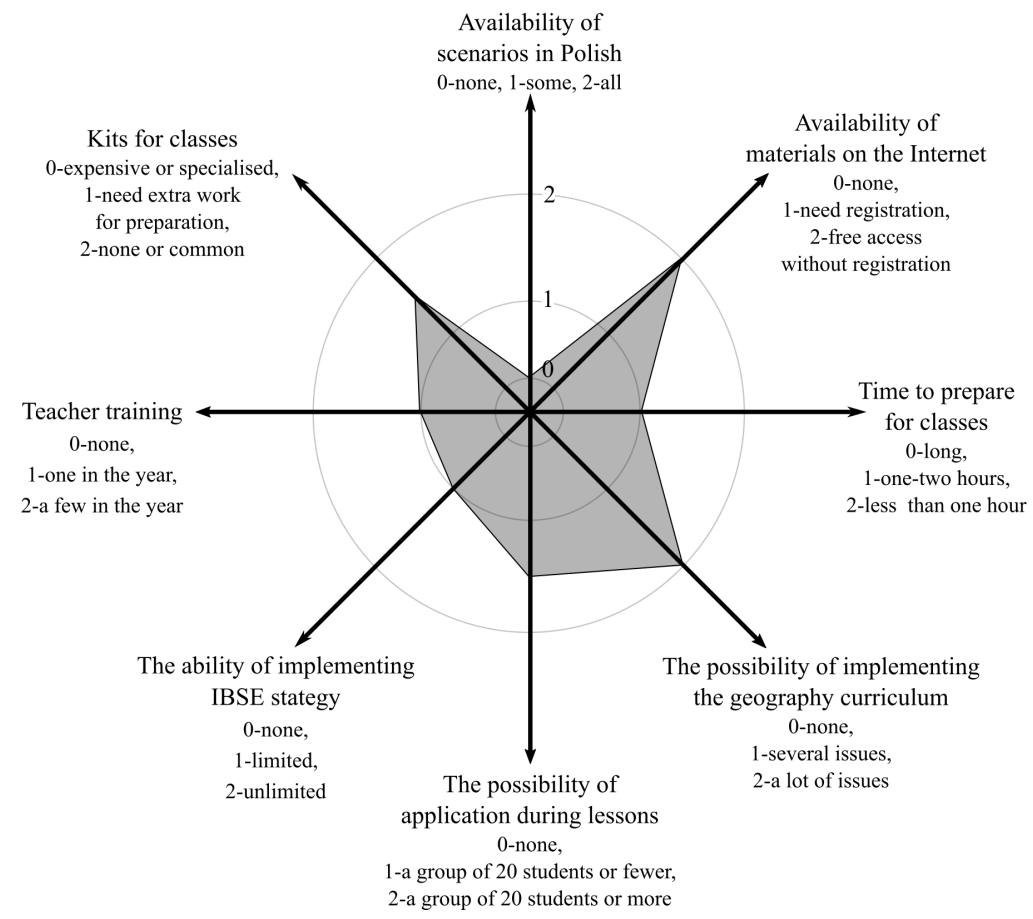

Figure 4. Space Awareness evaluation chart

Source: prepared on the basis of the teachers' workshop, Izera Dark-Sky Park 2017

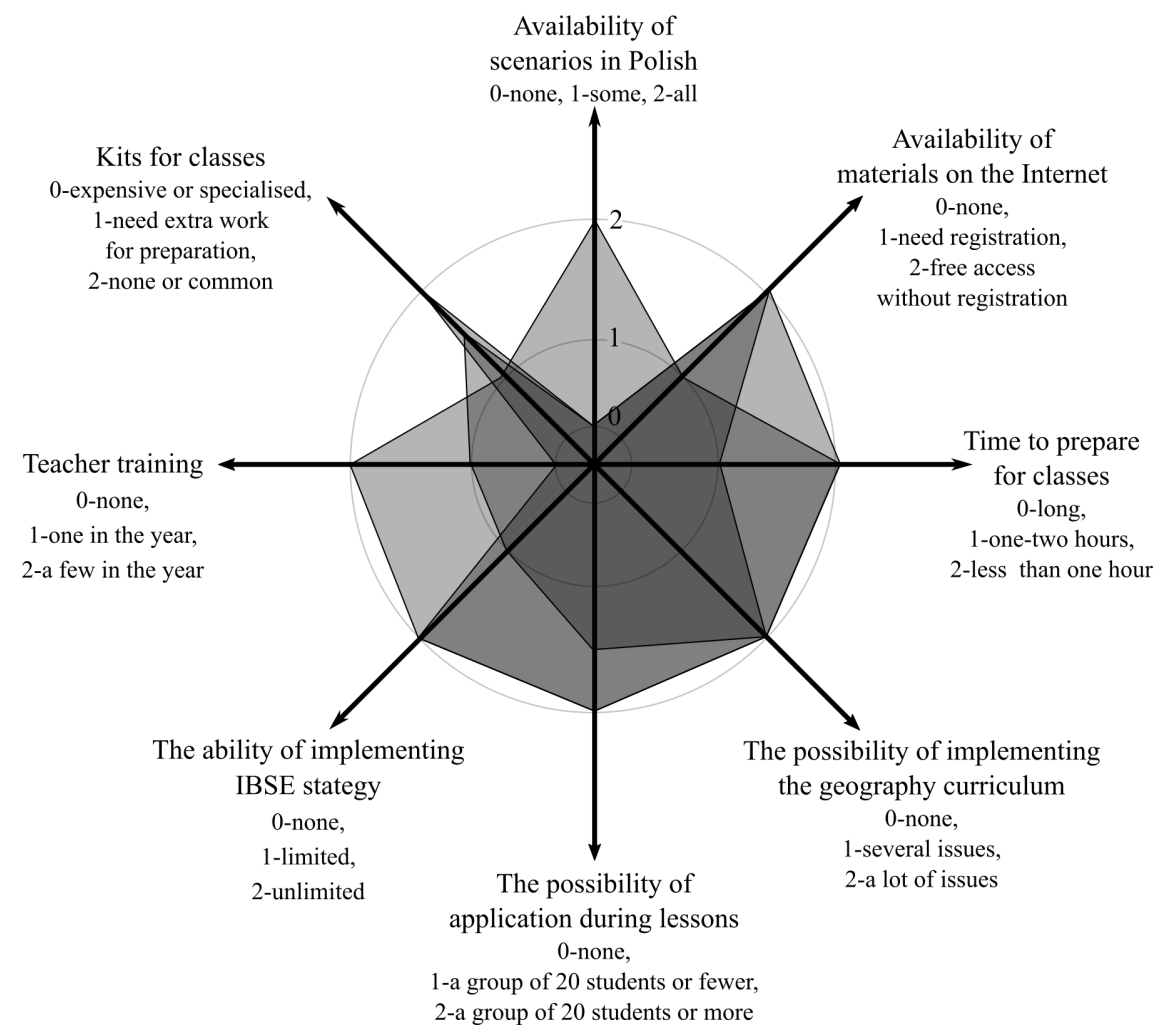

Figure 5. The combination of Space educational proposals Source: prepared by J. Sypniewski 
inquiry methods. It also recommends helping the student in constructing his or her own knowledge. Students at school are not customers but citizens and they have specified duties and they are responsible for them (Dylak 2013). The co-responsibility of the students for the process of education involves suggesting topics that can help their development in the area of geography. Space, which is so common in literature, the Internet or culture, can be the subject of greater interest in geography in primary schools. The New Curriculum gives the teacher an opportunity by offering him or her time that can be managed according to his or her choice. It must be stressed that the involvement of geographers in educational proposals offered by Polish partners as far as Space education is concerned is still low. This article presents a few selected proposals for education initiatives which can be implemented in geography lessons in primary schools and which refer to Space.

Space education supports geography education by introducing topics that encourage the students to look for information on their own with the help of elements of the IBSE strategy. In primary school the students can not only carry out observations or perform geographic and scientific experiments on their own, but in higher grades they also have the possibility to design and plan. The participants of the classes fully take to the initiative; they create tasks on their own, frequently using intuition; they try, and know that they can make mistakes which will force them to look for new solutions. Teachers seeking an inquiry orientation should focus on the nature of student work, the students' role and their own role (Anderson 1983).

The common aim of geography and Space science, which is the promotion of the research method and scientific inquiry as well as inspiring young people to choose careers connected with these sciences together with developing key competences (in line with the recommendation of the European Parliament), e.g. learning or the development of scientific and technical competences, are an additional argument for the introduction of Space topics in geography teaching.

\section{Acknowledgements}

I'm much obliged to Joanna Borucka and Katarzyna Kłopska for their their great help in translating the text.

\section{References}

Allen, PA 2000, Procesy zewnętrzne kształtujące powierzchnię Ziemi [Earth Surface Processes], Wydawnictwo Naukowe PWN, Warszawa.

Anderson, RD 2002, 'Reforming science teaching: What research says about inquiry', Journal of Science Teaching Education, vol. 13(1), pp. 1-12.

Balzano, E 2016. 'Inquiry-Based Science Education: perspectives and difficulties', Atti della Accademia Nazionale dei Lincei, Classe di Scienze Fisiche, Matematiche e Naturali, Rendiconti Lincei Matematica E Applicazioni, pp. 11-24.

Bell, P, Davis, EA \& Linn, MC (eds.) 1995, 'The Knowledge Integration Environment: Theory and Design', Proceeding CSCL '95 The first international conference on Computer support for collaborative learning, Indiana University, Bloomington. DOI: 10.3115/222020.222043

Bell, RL, Smetana, L \& Binns, I 2005, 'Simplifying inquiry instruction', The Science Teacher, vol. 72(7), pp. 30-33.

Bernard, P, Białas, A, Broś, P, Ellermeijer, T, Kędzierska, E, Krzeczkowska, M, Maciejowska, I, Odrowąż, E \& Szostak, E 2013, 'Podstawy metodologii IBSE' in Nauczenie przedmiotów przyrodniczych kształtujące postawy $i$ umiejętności badawcze uczniów ['Basics of the IBSE methodology' in Inquiry based science education], eds I Maciejowska \& E Odrowąż, vol. 1, Wydział Chemii, Uniwersytet Jagielloński, pp. 9-17.

Bryson, B 2003, Krótka historia prawie wszystkiego [A Short History of Nearly Everything], Zysk i S-ka, Poznań.

Bybee, RW 1989, Science and technology education for the elementary years: Frameworks for curriculum and instruction, Washington, DC: Office of Educational Research and Improvement (ED).

Chojnicki, Z 1999, Podstawy metodologiczne i teoretyczne geografii [Methodology and theory of geography], Bogucki Wydawnictwo Naukowe, Poznań.

Cichoń, M \& Piotrowska, I 2016, 'Neurodydaktyka w procesie kształcenia geograficznego' in Nowe problemy i metody badań procesu kształcenia geograficznego ['Neurodidactics in the proces of geographical education' in New problems and research methods in geography education, eds I Piotrowska \& E Szkurłat, Prace Komisji Edukacji Geograficznej Polskiego Towarzystwa Geograficznego vol. 6, Bogucki Wydawnictwo Naukowe, Poznań, pp. 97-113.
Czachorowski, S 2017, Tydzień cudów, czyli co tam, panie, w szkołach słychać? [A week of miracles, so what sounds at school?] 29 August 2017. Stanisław Czachorowski: Blog. Available from: <http://czachorowski.blox.pl/html/ page/4. html>. [4 September 2017].

Dunne, J, Abdulhussain, E, Mahdi, AE \& O'Reilly, J 2013, 'Investigating the potential of Irish Primary School textbooks in supporting inquiry-based science education (IBSE)', International Journal of Science Education, vol. 35(9), pp. $151-1532$.

Dylak, S 2013, Architektura wiedzy w szkole [Knowledge architecture at school], Difin, Warszawa.

European Space Education Resource Office, 2017. Available from: <http://esero.kopernik.org.pl/>. [16 November 2017].

Heinz, J, Enghag, M, Stuchlikova, I, Cakmakci, G, Peleg, R \& Baram-Tsabari, A 2017, 'Impact of initiatives to implement science inquiry: a comparative study of the Turkish, Israeli, Swedish, and Czech science education systems', Cultural Studies of Science Education, vol. 12, pp. 677-708.

Klus-Stańska, D 2010, Konstruowanie wiedzy w szkole [Constructing knowledge at school], Wydawnictwo Uniwersytetu Warmińsko-Mazurskiego, Olsztyn.

Kopeć, K 2005, Współczesne formy i metody w dydaktyce geografii [Contemporary forms and methods in didactics Geography], Bernardinum, Gdynia-Pelpin.

Kożuchowski, K 2005, Meteorologia i klimatologia [Meteorology and climatology], Wydawnictwo Naukowe PWN, Warszawa.

Lawson, AE 1958, Language, thought and the human mind, Michigan State University Press.

Lawson, AE, Abracham, MR \& Renner, JW 1989, A theory of instruction: Using the learning cycle to teach science concepts and thinking skills, NARST Monograph, Number One.

Łobocki, M 2000, Metody i techniki badań pedagogicznych [Methods and techniques of pedagogical research], Oficyna Wydawnicza Impuls, Kraków.

O ESERO. Available from: <http://esero.kopernik.org.pl/?page_ id=4>. [14 November 2017].

Pawłowski, S 1938, Geografia jako nauka i przedmiot nauczania [Geography as a science and subject of teaching], KsiążnicaAtlas, Lwów-Warszawa.

Podstawa Programowa Kształcenia Ogólnego Geografia - klasy V-VIII [Core Curriculum 2017 Geography - classes V- 
MISCELLANEA GEOGRAPHICA - REGIONAL STUDIES ON DEVELOPMENT

Vol. 23 • No. 4 • 2019 • pp. 256-266 • ISSN: 2084-6118 • DOI: 10.2478/mgrsd-2019-0024

VIII], 2017. Available from: <https://men.gov.pl/wp-content/ uploads/2016/11/geografia-podstawa.pdf>. [12 October 2017].

Rocard report 2007, Science education now: Anewpedagogy forthe future of Europe. Available from: <https://www. eesc.europa. eu/sites/default/files/resources/docs/ rapportrocardfinal.pdf>. [10 January 2018].

Rundgren, CJ 2016, 'Implementation of inquiry-based science education in different countries: some reflections', Cultural Studies of Science Education. DOI: 10.1007/s11422-0169787-8

Sally Ride Science, 2014. Available from: <http://esero.kopernik. org.pl>. [5 November 2017].

Sypniewski, J 2015a, 'Influence of the strategy of the Inquiry Based Science Education on the development of natural interests of students and acquiring natural-geographical competences in the course of extracurricular activities of natural science activity group'. Master's thesis, Adam Mickiewicz University, Poznań.

Sypniewski, J 2015b, 'Nauczanie przez odkrywanie odpowiedzią na współczesne wymagania w edukacji przyrodniczej' [IBSE as answer to modern requirements in nature education], Przegląd Wielkopolski, vol. 3, pp. 65-68.

Szarucki, M 2010, 'Metodyka analizy porównawczej w badaniach międzynarodowych' [Methodology of comparative analysis in international research], Zeszyty Naukowe $n r$ 827 Uniwersytetu Ekonomicznego w Krakowie, Wyd. Uniwersytetu Ekonomicznego, Kraków.

Sztumski, J 1999, Wstęp do metod i technik badań społecznych [Introduction to social research methods and techniques], Wyd. Śląsk, Katowice.

Tkocz, J 2008, 'Podstawy geografii społeczno-ekonomicznej: wykład teoretyczny' [Basics of socio-economic geography: theoretical lecture ] in Podręczniki i Skrypty Uniwersytetu Śląskiego w Katowicach' ed. G Wojdała, Podręczniki $i$ Skrypty Uniwersytetu Śląskiego w Katowicach, vol. 100, Wydawnictwo Uniwersytetu Śląskiego, Katowice, pp. 13-58.

Uum van Martina, SJ, Verhoeff, RP \& Peeters, M 2016, 'Inquirybased science education: towards a pedagogical framework for primary school teachers', International Journal of Science Education, vol. 38(3), pp. 450-469.

Wiecki, W 2018, 'Pułapki edukacji geograficznej. Refleksje nauczyciela geografii' [Geographic educational trap] in. Nauczyciel geografii wobec wyzwań reformowanej szkoły, eds A Hibszer \& E Szkurłat, Prace Komisji Edukacji Geograficznej Polskiego Towarzystwa Geograficznego, vol. 8, Bogucki Wydawnictwo Naukowe, Poznań, pp. 193-199.

Woś, A 2006, Meteorologia dla geografów [Meteorology for geographers], Wydawnictwo Naukowe UAM, Poznań. Institute of Physic: A brief history of space. Available from: <http:// www.iop.org/resources/topic/archive/space>. [25 October 2017].

Zieliński, J 2012, Metodologia pracy naukowej [Methodology of scientific work], Oficyna Wydawnicza ASPRA-JR, Warszawa. 